\title{
Rice cultivar selection in an agroforestry system through GGE-biplot and EBLUP
}

\author{
TAUFAN ALAM $^{1, \bullet}$, PRIYONO SURYANTO ${ }^{2}$, SUPRIYANTA ${ }^{1}$, PANJISAKTI BASUNANDA ${ }^{1}$, \\ RANI AGUSTINA WULANDARI ${ }^{1}$, DODY KASTONO ${ }^{1}$, MUHAMMAD HABIB WIDYAWAN ${ }^{1}$, \\ NURMANSYAH ${ }^{1}$, TARYONO ${ }^{1,3}$ \\ ${ }^{1}$ Department of Agronomy, Faculty of Agriculture, Universitas Gadjah Mada. Jl. Flora No. 1, Bulaksumur, Sleman 55281, Yogyakarta, Indonesia. \\ Tel./fax.: +62-274-563062, `email: taufan.alam@ugm.ac.id \\ ${ }^{2}$ Department of Silviculture, Faculty of Forestry, Universitas Gadjah Mada. Jl. Flora No. 1, Bulaksumur, Sleman 55281, Yogyakarta, Indonesia \\ ${ }^{3}$ Agrotechnology Innovation Center, Universitas Gadjah Mada. Jl. Kalitirto, Berbah, Sleman 55573, Yogyakarta, Indonesia
}

Manuscript received: 8 July 2021. Revision accepted: 12 October 2021.

\begin{abstract}
Alam T, Suryanto P, Supriyanta, Basunanda P, Wulandari RA, Kastono D, Widyawan MH, Nurmansyah, Taryono. 2021. Rice cultivar selection in an agroforestry system through GGE-biplot and EBLUP. Biodiversitas 22: 4750-4757. Genotype-by-environment interaction (GEI) causes differences in the productivity of rice cultivars in agroforestry systems. For this reason, the stability of rice cultivars is an important aspect that should be considered before a cultivar is recommended to farmers. Superior genotypes and ideal environments are commonly identified using two statistical models, namely, genotype-genotype-by-environment biplot (GGE-biplot) and empirical best linear unbiased prediction (EBLUP). In this study, 15 rice cultivars were evaluated in terms of their productivity and stability in three soil types (Lithic Haplusterts, Ustic Epiaquerts, and Vertic Haplustalfs) in an agroforestry system with kayu putih (Melaleuca cajuputi) in 2019 and 2020 at the Menggoran Forest Resort, Playen Forest Section, Yogyakarta Forest Management District, Indonesia. The cultivars were treated as random effects to select and obtain the EBLUP of the best cultivars in each soil type. The EBLUP revealed that Situ Patenggang showed the highest yields of 4.887 and 5.456 tons ha ${ }^{-1}$ in Lithic Haplusterts and Vertic Haplustalfs, respectively. GM 28 exhibited the highest yield of 6.492 tons ha $^{-1}$ in Ustic Epiaquerts. Ciherang, GM 2, GM 8, GM 11, GM 28, Inpari 6 Jete, Inpari 33, IR-64, and Way Apo Buru were classified as stable and fairly stable cultivars, whereas the other cultivars were unstable. Therefore, rice cultivars with high yields in specific soil types should be selected.
\end{abstract}

Keywords: agroforestry, Melaleuca cajuputi, rice cultivars, selection, soil types

Abbreviations: AEC: Average environment coordination, $\mathrm{C} \cdot \mathrm{S}$ : Cultivar-by-soil type interaction, EBLUP: Empirical best linear unbiased prediction, GEI: Genotype-environment interaction, GGE-biplot: Genotype-genotype-by-environment biplot, R: Replicate, C: Rice cultivars, S: Soil types, VCOV: Variance-covariance

\section{INTRODUCTION}

Rice is a staple food and the main source of income of farmers with land ownership of less than 1 hectare (FAO 2019). In Indonesia, rice production decreased by 4.60 million tons or $7.76 \%$ in 2019 compared with that in 2018 . One of the problems related to this decline in rice production is a reduction of 10.68 million hectares or $6.15 \%$ in planting areas (Statistics Indonesia 2020). By 2045, 8.1 million hectares of rice fields in Indonesia will have been reduced to 5.1 million hectares (Mulyani et al. 2017). One alternative solution to this problem is intensifying rainfed areas in an agroforestry system for cultivating food crops, especially rice (Mulyani et al. 2017; Suryanto et al. 2020b).

Agroforestry is a land-use system and technology that integrates woody perennials with annual crops and animals in the same land management unit (FAO 2015). The potential for kayu putih forests in Indonesia is 248,756 hectares (Kartikawati et al. 2014). Land intensification among kayu putih (Melaleuca cajuputi) stands beneficial because the leaves and branches of $M$. cajuputi are pruned twice a year; as such, no shade effect on rice occurs and the root zone differential lessens the conflict for nutrients and water (Suryanto et al. 2020b). One solution to increase national rice production is to use superior rice cultivars with high yields and stability under various environmental conditions. Cultivars are the easiest and cheapest technologies used by farmers. Their suitability under specific environmental conditions is one of the key factors to maximize yield potential (Piepho et al. 2016). In addition, cultivars suitable for the environment streamline the input of inorganic fertilizers in compliance with the principles of sustainable agriculture (European Union 2012).

Genotype-by-environment interaction (GEI) is a phenomenon that causes differences in cultivar productivity in various environments. It causes difficulties in selecting ideal and stable cultivars for all environmental conditions (Eberhart and Russell 1966; Finlay and Wilkinson 1963; Yan et al. 2007). Nevertheless, a multi-environment trial (MET) is performed to assess the effect of GEI and select stable cultivars. This method is used to evaluate the genotype, environment, and their interactions and is 
composed of several statistical methods, including univariate and multivariate ones. The commonly used multivariate methods are genotype-genotype-byenvironment biplot (GGE-biplot) and empirical best linear unbiased prediction (EBLUP). A GGE-biplot graph can provide visual information about the evaluation of genotype, environment, and their interactions (Yan et al. 2003; Yan et al. 2007). The GGE-biplot can be used to evaluate stability and adaptability (specific or broad) (Gerrano et al. 2020). In GGE-biplot, grain yield stability is evaluated using average environment coordination (AEC) (Bilgin et al. 2015; Oladosu et al. 2017). The EBLUP is used for a specific environment to borrow strength/information from other environments (Buntaran et al. 2019; Buntaran et al. 2020; Buntaran et al. 2021; Kleinknecht et al. 2013; Piepho et al. 2016). Alam et al. (2019a) used the EBLUP to estimate the yield of soybean varieties on various soil types in an agroforestry system with $M$. cajuputi. They showed that the Dering I variety has the highest yield in Lithic Haplusterts and Ustic Epiaquerts, whereas the Burangrang variety has the lowest yield in Vertic Haplustalfs.

This study aimed to determine the best estimate of 15 rice cultivars in an agroforestry system containing $M$. cajuputi with three soil types, namely, Lithic Haplusterts, Ustic Epiaquerts, and Vertic Haplustalfs. Thus, this study could provide farmers, scientists, and policymakers with information and options regarding stable, high-yielding rice cultivars in agroforestry systems with $M$. cajuputi.

\section{MATERIALS AND METHODS}

\section{Study site}

This study was conducted from November 2019 to February 2020 in Menggoran Forest Resort, Playen Forest Section, Yogyakarta Forest Management District, Indonesia (Figure 1a). The study site is at an altitude of \pm 100 meters above sea level and has a ustic moisture regime: annual mean temperature, relative humidity, and precipitation of $29.38{ }^{\circ} \mathrm{C}, 81.90 \%$, and $1,182 \mathrm{~mm} \mathrm{year}^{-1}$, respectively (Alam et al. 2019a; Alam et al. 2019b; Alam et al. 2021; Suryanto et al. 2017; Suryanto et al. 2020b). This regime is composed of limited moisture but is suitable for plant growth when environmental conditions are favorable and when the water requirements for plants are met (Boettinger et al. 2015).

\section{Multi-environment trial}

A randomized complete block design factorial with five blocks as replications were prepared in three soil types (Lithic Haplusterts, Ustic Epiaquerts, and Vertic Haplustalfs). Fifteen rice cultivars were used: 11 major rice varieties (Ciherang, Inpago 4, Inpago 5, Inpago 6, Inpari 6 Jete, Inpari 33, IR-64, Puthu Gunungkidul, Situ Bagendit, Situ Patenggang, and Way Apo Buru) from the Indonesian Center for Rice Research (ICRR), West Java, Indonesia, and four promising lines (GM 2, GM 8, GM 11, and GM 28) from the Faculty of Agriculture, Universitas Gadjah Mada, Indonesia.

Experimental plots were placed between $M$. cajuputi stands of $24 \mathrm{~m}^{2}(6 \mathrm{~m} \times 4 \mathrm{~m})$. The harvest area for rice was $20 \mathrm{~m}^{2}$, and border crops were excluded. Minimum soil tillage was performed before the rice was planted via direct seeding with $20 \mathrm{~cm} \times 20 \mathrm{~cm}$ spacing and two seeds per planting hole (Figure 1b). Fertilization and other cultivation techniques were implemented as recommended by the ICRR. The organic fertilizer made from cow manure of 10 tons $\mathrm{ha}^{-1}$ was applied before planting and urea fertilizer of $300 \mathrm{~kg} \mathrm{ha}^{-1}$ was applied when the rice reached one and eight weeks after planting (WAP). SP-36 and $\mathrm{KCl}$ fertilization were applied at 100 and $150 \mathrm{~kg} \mathrm{ha}^{-1}$ after one WAP, respectively. Irrigation was not carried out during the study as it was situated in a rainfed area.

\section{Data collection}

The observed parameter was rice yield per hectare. Rice grains were sun-dried to reach the moisture level of $11 \%$. (Suryanto et al. 2020a; Suryanto et al. 2020b). Measuring the moisture content of the seeds using the AMTAST JV002 series grain moisture tester.

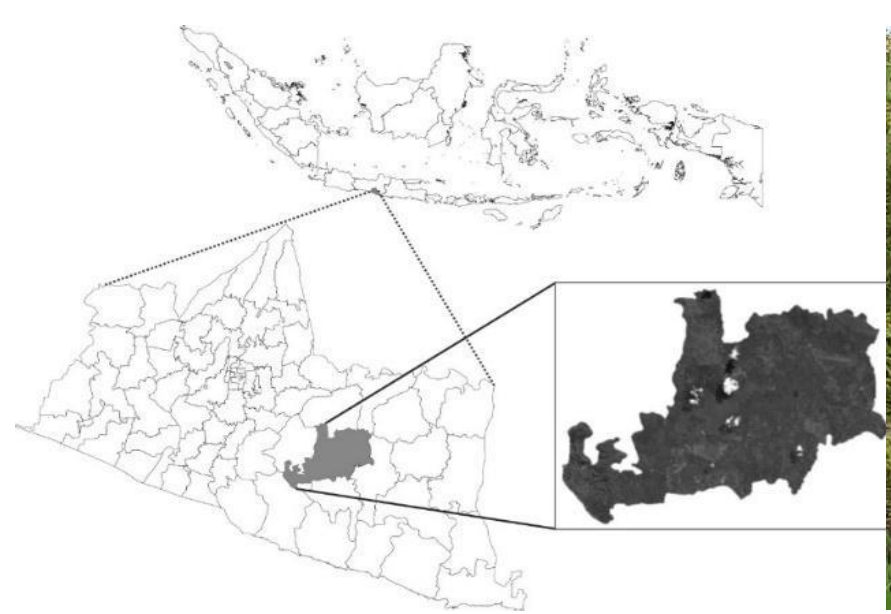

A

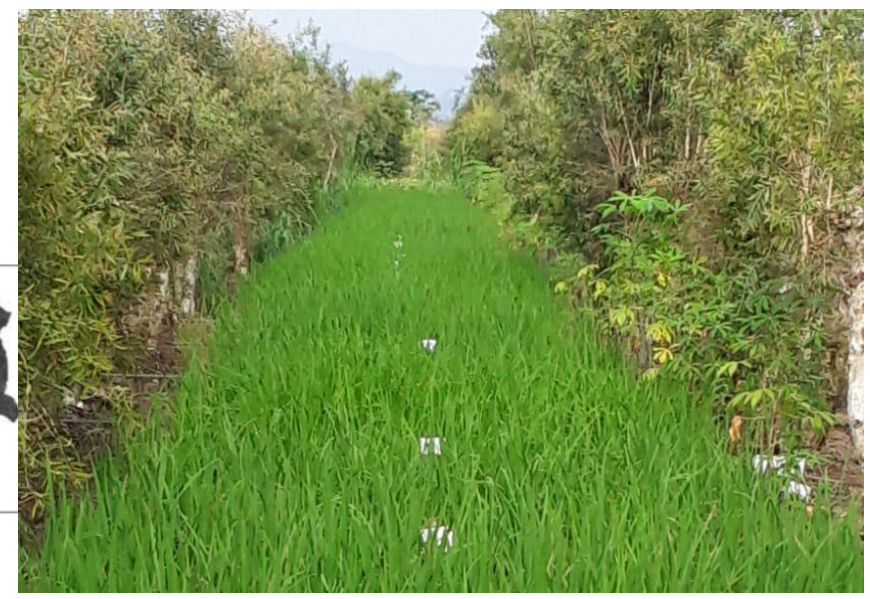

B

Figure 1. A. Geographical locations of the study site (latitude $7^{\circ} 52^{`} 59.5992^{\prime} \mathrm{S}$ to $7^{\circ} 59^{`} 41.1288^{\prime} \mathrm{S}$ and longitude $110^{\circ} 26^{`} 21.462^{\prime \prime} \mathrm{E}$ to $110^{\circ} 35^{\prime} 7.4868^{\prime \prime}$ E) (Alam et al. 2019a, B. Rice cultivars between M. cajuputi stands 
Table 1. Factors for the analysis of rice cultivars in $M$. cajuputi agroforestry system by using linear mixed models

\begin{tabular}{lcc}
\hline Factors & Number of levels & Symbols \\
\hline Soil types & 3 & $\mathrm{~S}$ \\
Rice cultivars & 15 & $\mathrm{C}$ \\
Replicate & 5 & $\mathrm{R}$ \\
\hline
\end{tabular}

\section{Statistical analysis}

The following model was used (Alam et al. 2019a):

Rice cultivars $\times$ (soil types / replicate $)=$ soil types: replicate + rice cultivars + rice cultivars $\bullet$ soil types

Where: fixed and random effects are indicated before and after the colon; the cross effect is denoted by the dot between the two factors; $\mathrm{C} \cdot \mathrm{S}$ is the interaction between a cultivar and a soil type; and replication is nested in the soil type. The random effects on the covariance structure for each treatment factor were described as follows:

The covariance structure for replicate $(R)$ is $\mathbf{G}_{R}=\oplus_{j=\mathbb{1}}^{J} \mathbf{G}_{R(j)}$, where $\mathbf{G}_{R[j]}$ is a diagonal matrix with diagonal elements $\sigma_{R(j)}^{2}$. A certain soil type variance was assumed (i). The covariance structure for the cultivar effect is the identity structure, namely, $\mathbf{G}_{\mathrm{V}}=\sigma^{2} \mathrm{I}$ (ii). The residual covariance structure is heterogeneous with soil type-specific $\mathbf{R}=\oplus_{j=1}^{J} \mathbf{R}_{j}$, where $\mathbf{R}_{j}$ is a diagonal matrix with $\sigma_{\varepsilon[j]}^{2}$ (iii)

A model was created for the variances of $\mathrm{C} \cdot \mathrm{S}$ in the baseline linear model based on the cultivar to assess the stability of cultivars. $\mathrm{C}$ and $\mathrm{C} \cdot \mathrm{S}$ were set as random effects to estimate the cultivar effects per soil type with borrowing strength across soil types. This estimate was called EBLUP because the cultivars were assigned a random effect. The term "empirical" was used because variance components are unknown and thus should be estimated (Littell et al. 2006).

The base model was re-parameterized by removing the main $\mathrm{C}$ effect, and the $\mathrm{C} \cdot \mathrm{S}$ effect was dropped using $\mathrm{C}$ as the subject effect to apply a different variance-covariance (VCOV) model of the $\mathrm{C} \cdot \mathrm{S}$ term. The soil type-specific genetic effects of $\mathrm{C} \cdot \mathrm{S}$ for the same cultivar were correlated between soil types. Thus, BLUPs for a specific environment can borrow information from soil types (Buntaran et al. 2019; Buntaran et al. 2020; Buntaran et al. 2021; Kleinknecht et al. 2013; Piepho et al. 2016).

Modeling based on the generalization of the variance stability model was performed to assess cultivar stability (Shukla 1972). The $\mathrm{C}$ and $\mathrm{C} \cdot \mathrm{S}$ effects were used as random effects to estimate the cultivar effect per soil type by borrowing information across soil types. The EBLUP and Shukla models were utilized with PROC MIXED in SAS 9.4 software (SAS Institute 2013).

Data were analyzed graphically to interpret GEIs by using the GGE-biplot technique (Yan 2007). The graphs were based on a which-won-where pattern, AEC, and a genotype-focused scaling pattern based on angles between soil type vectors. The GGE-biplot was analyzed with Genstat $18^{\text {th }}$ edition (Goedhart and Thissen 2016).

\section{RESULTS AND DISCUSSION}

\section{Site characteristics}

The soil types in the study area were classified as Lithic Haplusterts, Vertic Haplustalfs, and Ustic Epiaquerts (Alam et al. 2019a; Alam et al. 2020; Alam et al. 2021; Suryanto et al. 2017; Suryanto et al. 2020a; Suryanto et al. 2020b). Lithic Haplusterts is included in Vertisol, which shrinks under dry conditions and expands under wet conditions. It is shallow $(<50 \mathrm{~cm})$ and has a rock contact (Boettinger et al. 2015). Vertic Haplustalfs belongs to Alfisols with a Vertic characteristic. Ustic Epiaquerts is also a Vertisol that is flooded for more than 6 months; under dry conditions, cracks form $(>5 \mathrm{~mm}$ wide and $>25$ $\mathrm{cm}$ thick) (Soil Survey Staff 2014).

Soil analysis results showed that all soil parameters (physical, chemical, and biological) showed significant to very significant differences between soil types except the availability of $\mathrm{Mn}$ and $\mathrm{Al}$. The soil texture in the study area was generally dominated by clay texture, the $\mathrm{pH}$ of $\mathrm{H}_{2} \mathrm{O}$ was alkaline, and CEC was high. Soil organic carbon content (SOC), total $\mathrm{N}$, and $\mathrm{P}$ availability were low, whereas K availability was moderate (Table 2) (Suryanto et al. 2020). Lithic Haplusterts and Vertic Haplustalfs were marginally suitable for rice because both tend to be rainfed areas. Ustic Epiaquerts was also favorable to rice growth because it is a flooded basin area during the wet season (Djaenudin et al. 2011).

\section{Ranking and EBLUP of 15 cultivars in each soil type}

The ranking of rice cultivars in various soil types is presented in Table 3. The EBLUP showed that Situ Patenggang showed the highest yield of 4.887 tons $^{-1}$ in Lithic Haplustert, whereas Puthu Gunungkidul had the lowest yield of 2.078 tons ha $^{-1}$. Situ Patenggang and Puthu Gunungkidul cultivars had the highest and lowest yields of 5.456 and 2.486 tons $\mathrm{ha}^{-1}$ in Vertic Haplustalfs, respectively. In Ustic Epiaquerts, GM 28 had the highest yield of 6.492 tons $\mathrm{ha}^{-1}$, whereas Inpago 6 had the lowest yield of 2.081 tons $\mathrm{ha}^{-1}$. If the effect model remains when

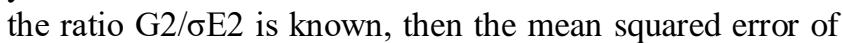
the EBLUP is smaller than that of the best linear unbiased estimates (Forkman and Piepho 2013).

The rice cultivar rankings are different among the three soil types; as such, the genetic correlation is low (Table 4). $\mathrm{C}$ and $\mathrm{C} \cdot \mathrm{S}$ models are random, so strength across different environments, i.e. soil types, may be borrowed. The $\mathrm{C} \cdot \mathrm{S}$ model reduces the degree of shrinkage compared with that of other models. The independent (ID) model likely has more shrinkage than the $\mathrm{C} \cdot \mathrm{S}$ model. The degree of shrinkage in the $\mathrm{C} \cdot \mathrm{S}$ model allows borrowing strength across soil types, whereas the ID model only uses information from the targeted soil type. Cultivars are set as random effects because the analysis aims to select the best cultivar in each soil type. Smith et al. (2005) stated that the estimated cultivar effect rating should be as accurate as of the actual cultivar effect rating in the selection of the best variety, which requires the best prediction for the true effect. 
Table 2. Soil characteristics in this study (Suryanto et al. 2020b)

\begin{tabular}{|c|c|c|c|c|c|}
\hline \multirow{2}{*}{ Soil characteristics } & \multirow{2}{*}{ Symbols } & \multirow{2}{*}{ Unit } & \multicolumn{3}{|c|}{ Soil types } \\
\hline & & & Lithic haplusterts & Ustic epiaquerts & Vertic haplustalfs \\
\hline \multicolumn{6}{|l|}{ Physical } \\
\hline Soil texture & ST & - & Clay & Clay & Clay \\
\hline Bulk density & $\mathrm{BD}$ & $\mathrm{g} \mathrm{cm}^{-3}$ & 1.16 & 1.10 & 1.10 \\
\hline Soil moisture content & SMC & $\mathrm{mm} \mathrm{cm}^{-1}$ & 27.65 & 74.26 & 45.08 \\
\hline Permeability & $\mathrm{h}$ & $\mathrm{cm} \mathrm{h}^{-1}$ & 0.001 & 0.001 & 0.001 \\
\hline \multicolumn{6}{|l|}{ Chemical } \\
\hline $\mathrm{pH} \mathrm{H}_{2} \mathrm{O}$ & $\mathrm{pH}$ & - & 8.16 & 7.90 & 7.63 \\
\hline Soil organic carbon & SOC & $\%$ & 1.52 & 1.66 & 1.53 \\
\hline Cation exchange capacity & CEC & $\mathrm{cmol}^{(+)} \mathrm{kg}^{-1}$ & 58.78 & 66.54 & 32.42 \\
\hline Electrical conductivity & $\mathrm{EC}$ & $\mathrm{dS} \mathrm{m}^{-1}$ & 1.69 & 1.91 & 1.06 \\
\hline Total nitrogen & $\mathrm{N}$ & $\%$ & 0.13 & 0.18 & 0.12 \\
\hline \multicolumn{6}{|l|}{ Soil nutrient availability: } \\
\hline Phosphorus & $\mathrm{P}$ & $\mathrm{ppm}$ & 6.81 & 11.39 & 3.38 \\
\hline Potassium & $\mathrm{K}$ & $\mathrm{cmol}^{(+)} \mathrm{kg}^{-1}$ & 0.41 & 0.50 & 0.31 \\
\hline Sodium & $\mathrm{Na}$ & $\mathrm{cmol}^{(+)} \mathrm{kg}^{-1}$ & 0.63 & 0.66 & 0.12 \\
\hline Calcium & $\mathrm{Ca}$ & $\mathrm{cmol}^{(+)} \mathrm{kg}^{-1}$ & 27.18 & 24.51 & 21.02 \\
\hline Magnesium & $\mathrm{Mg}$ & $\mathrm{cmol}^{(+)} \mathrm{kg}^{-1}$ & 1.77 & 2.86 & 1.34 \\
\hline Iron & $\mathrm{Fe}$ & $\mathrm{ppm}$ & 1.22 & 1.29 & 4.40 \\
\hline Manganese & $\mathrm{Mn}$ & $\mathrm{ppm}$ & 3.25 & 3.37 & 3.61 \\
\hline Aluminum & $\mathrm{Al}$ & ppm & 1.51 & 1.51 & 1.76 \\
\hline \multicolumn{6}{|l|}{ Biological } \\
\hline Total bacteria & $\mathrm{Bac}$ & colony & $3.43 \times 10^{6}$ & $3.57 \times 10^{6}$ & $3.47 \times 10^{6}$ \\
\hline Total fungi & $\mathrm{Fg}$ & colony & $2.50 \times 10^{5}$ & $2.67 \times 10^{5}$ & $2.53 \times 10^{5}$ \\
\hline
\end{tabular}

In the re-parameterization of the $\mathrm{C} \cdot \mathrm{S}$ model $(\mathrm{VCOV}), \mathrm{C}$ is used as the subject, and the cultivar effect is excluded. The influence of genetic factors on certain soil types shows that $\mathrm{C} \cdot \mathrm{S}$ for the same cultivar is correlated with soil type; as such, the EBLUP can be used (Buntaran et al. 2019; Buntaran et al. 2020; Buntaran et al. 2021; Kleinknecht et al. 2013; Piepho et al. 2016). However, any lack of genetic correlation between environments corresponds to a GEI. Therefore, several VCOV models for $\mathrm{C} \bullet \mathrm{S}$ were fitted: ID, compound symmetry, heterogeneous compound symmetry, and UN (Piepho et al. 2016).

Rice cultivars planted on each type of soil have different yields per hectare. These differences indicate a GEI between cultivars and soil types. Genetic factors influence rice productivity in each cultivar (Klee and Tieman 2013). Giller et al. (2011) informed that different genetics between rice cultivars cause various responses to nutrient absorption, water absorption, and fertilizer application time. This finding indicates a high heterogeneity between soil types, thereby affecting the growth and yield of rice. Suryanto et al. (2020b) stated that differences in soil quality (physical, chemical, and biological) between Lithic Haplustert, Ustic Epiaquerts, and Vertic Haplustalfs cause variations in responses between rice cultivars.

Soil quality is determined by soil types and land management practices (Bilgili et al. 2017) and is considered an important element for plant growth. Each rice cultivar has different nutrient limiting factors, and rice cultivars exhibit different biochemical, physiological, and yield responses under various environmental conditions (Boy et al. 2020). The response of each rice cultivar to certain nutrients can explain why cultivars can grow well in each type of soil. Therefore, selecting the appropriate rice cultivar that can adapt to soil type can maximize the yield potential of rice cultivars and streamline inorganic fertilizer inputs (European Union 2012).

\section{Stability variance estimates through GGE-biplot}

The adaptability and stability of rice cultivars can be identified using the GGE-biplot method. In this method, the first two principal components $\left(\mathrm{PC}_{1}\right.$ and $\mathrm{PC}_{2}$, also referred to as primary and secondary effects, respectively) are derived by subjecting the environment-centered yield data (yield variation due to GGE) to singular value decomposition (Yan et al. 2003).

Visualization with the GGE-biplot revealed eight sectors, where each sector had a vertex genotype. Two sectors had an environment, and six sectors had none. This sector with an environment is called a mega environment (Mega-E). Within this sector is a vertex genotype, which is the outermost genotype that forms a polygon when it is connected to a connection line (Farshadfar et al. 2013). The vertex genotypes consisted of GM 2 (G2), GM-28 (G5), Inpago 6 (G8), Inpari 6 Jete (G9), IR-64 (G11), Puthu Gunungkidul (G12), Situ Bagendit (G13), and Situ Patenggang (G14). The genotype had the highest or lowest yield per hectare in some or all environments because the distance of the genotype was farthest from the biplot point. Vertex genotype is the best one on the environment in the same vector; therefore, each vertex genotype has the best local adaptation in each Mega-E (Figure 1b; Yan and Kang 2003). 
Table 3. Ranking, EBLUP, and standard error of 15 rice cultivars in each soil type

\begin{tabular}{|c|c|c|c|c|c|c|}
\hline Soil types & Rice cultivars & EBLUP & Std. Error & df & T-value & Probability \\
\hline Lithic haplusterts & $\begin{array}{l}\text { Situ Patenggang } \\
\text { GM } 28 \\
\text { GM } 8 \\
\text { GM } 11 \\
\text { Inpago } 4 \\
\text { Inpari } 33 \\
\text { Ciherang } \\
\text { Inpago } 5 \\
\text { Situ Bagendit } \\
\text { GM } 2 \\
\text { Way Apo Buru } \\
\text { Inpari 6 Jete } \\
\text { IR-64 } \\
\text { Inpago } 6 \\
\text { Puthu Gunungkidul }\end{array}$ & $\begin{array}{l}4.887 \\
4.764 \\
3.808 \\
3.223 \\
2.896 \\
2.645 \\
2.629 \\
2.606 \\
2.581 \\
2.489 \\
2.477 \\
2.248 \\
2.153 \\
2.104 \\
2.078\end{array}$ & $\begin{array}{l}0.7272 \\
0.7272 \\
0.7272 \\
0.6564 \\
0.7272 \\
0.6564 \\
0.7272 \\
0.7274 \\
0.06559 \\
0.7274 \\
0.7274 \\
0.6564 \\
0.7274 \\
0.6564 \\
0.7274\end{array}$ & $\begin{array}{l}40.8 \\
40.8 \\
40.8 \\
42.4 \\
40.8 \\
42.4 \\
40.8 \\
40.9 \\
30.3 \\
40.9 \\
40.9 \\
42.4 \\
40.9 \\
42.4 \\
40.9\end{array}$ & $\begin{array}{l}6.72 \\
6.26 \\
5.76 \\
6.14 \\
5.53 \\
5.83 \\
4.65 \\
3.86 \\
40.08 \\
3.47 \\
3.2 \\
3.31 \\
2.64 \\
2.88 \\
1.64\end{array}$ & $\begin{array}{l}<.0001 \\
<.0001 \\
<.0001 \\
<.0001 \\
<.0001 \\
<.0001 \\
<.0001 \\
0.0004 \\
<.0001 \\
0.0012 \\
0.0027 \\
0.0019 \\
0.0116 \\
0.0062 \\
0.0108\end{array}$ \\
\hline Ustic epiaquerts & $\begin{array}{l}\text { GM } 28 \\
\text { GM } 8 \\
\text { Inpari } 6 \text { Jete } \\
\text { Inpari } 33 \\
\text { GM } 11 \\
\text { GM } 2 \\
\text { Ciherang } \\
\text { IR-64 } \\
\text { Situ Patenggang } \\
\text { Way Apo Buru } \\
\text { Inpago } 4 \\
\text { Puthu Gunungkidul } \\
\text { Inpago } 5 \\
\text { Situ Bagendit } \\
\text { Inpago } 6\end{array}$ & $\begin{array}{l}6.492 \\
6.301 \\
6.188 \\
6.101 \\
5.876 \\
5.627 \\
4.965 \\
4.919 \\
4.070 \\
3.117 \\
2.747 \\
2.621 \\
2.568 \\
2.243 \\
2.081\end{array}$ & $\begin{array}{l}0.6555 \\
0.7277 \\
0.6555 \\
0.7277 \\
0.7277 \\
0.7273 \\
0.6555 \\
0.7273 \\
0.7273 \\
0.7277 \\
0.6555 \\
0.7273 \\
0.7273 \\
0.7277 \\
0.04174\end{array}$ & $\begin{array}{c}42.1 \\
40.9 \\
42.1 \\
40.9 \\
40.9 \\
40.8 \\
42.1 \\
40.8 \\
40.8 \\
40.9 \\
42.1 \\
40.8 \\
40.8 \\
40.9 \\
30\end{array}$ & $\begin{array}{l}9.86 \\
8.79 \\
8.87 \\
7.12 \\
5.84 \\
5.8 \\
6.28 \\
5.47 \\
5.39 \\
5.26 \\
5.53 \\
4.78 \\
4.68 \\
3.84 \\
61.53\end{array}$ & $\begin{array}{l}<.0001 \\
<.0001 \\
<.0001 \\
<.0001 \\
<.0001 \\
<.0001 \\
<.0001 \\
<.0001 \\
<.0001 \\
<.0001 \\
<.0001 \\
<.0001 \\
<.0001 \\
0.0004 \\
<.0001\end{array}$ \\
\hline Vertic haplustalfs & $\begin{array}{l}\text { Situ Patenggang } \\
\text { GM } 28 \\
\text { GM } 11 \\
\text { Inpari } 6 \text { Jete } \\
\text { Inpari } 33 \\
\text { GM } 8 \\
\text { Ciherang } \\
\text { Inpago } 4 \\
\text { GM } 2 \\
\text { Inpago } 5 \\
\text { Way Apo Buru } \\
\text { Situ Bagendit } \\
\text { IR-64 } \\
\text { Inpago } 6 \\
\text { Puthu Gunungkidul }\end{array}$ & $\begin{array}{l}5.456 \\
5.400 \\
4.370 \\
4.351 \\
4.232 \\
4.015 \\
3.087 \\
3.086 \\
2.973 \\
2.939 \\
2.919 \\
2.878 \\
2.868 \\
2.535 \\
2.486\end{array}$ & $\begin{array}{l}0.7271 \\
0.7278 \\
0.7278 \\
0.6558 \\
0.7271 \\
0.6558 \\
0.7271 \\
0.7278 \\
0.6558 \\
0.7278 \\
0.05136 \\
0.7271 \\
0.6558 \\
0.7278 \\
0.7271\end{array}$ & $\begin{array}{l}40.8 \\
40.9 \\
40.9 \\
42.2 \\
40.8 \\
42.2 \\
40.8 \\
40.9 \\
42.2 \\
40.9 \\
30.2 \\
40.8 \\
42.2 \\
40.9 \\
40.8\end{array}$ & $\begin{array}{l}7.62 \\
7.13 \\
7.08 \\
5.98 \\
5.22 \\
5.52 \\
4.9 \\
4.82 \\
4.86 \\
4.04 \\
56.82 \\
3.9 \\
4.01 \\
3.27 \\
2.1\end{array}$ & $\begin{array}{l}<.0001 \\
<.0001 \\
<.0001 \\
<.0001 \\
<.0001 \\
<.0001 \\
<.0001 \\
<.0001 \\
<.0001 \\
0.0002 \\
<.0001 \\
0.0004 \\
0.0002 \\
0.0022 \\
0.0421\end{array}$ \\
\hline
\end{tabular}

Table 4. Variance estimates $\left(10^{-3} \mathrm{~kg}^{2} \mathrm{ha}^{-2}\right)$ for the $\mathrm{C} \cdot \mathrm{S}$ model

\begin{tabular}{lll}
\hline Effect $\dagger$ & Group & Variance estimate \\
\hline $\mathrm{R}$ & Lithic Haplusterts & 0.000033 \\
& Ustic Epiaquerts & 0.000 \\
& Vertic Haplustalfs & 0.000 \\
$\mathrm{C} \cdot \mathrm{S} \ddagger$ & Genetic variance $(\mathrm{C})$ & 0.794 \\
& Genetic correlation§ & 0.742 \\
$\mathrm{E}$ & Lithic Haplusterts & 0.013 \\
& Ustic Epiaquerts & 0.005 \\
& Vertic Haplustalfs & 0.008 \\
\hline
\end{tabular}

Note: $\nmid R$ : Replicate; C•S: Cultivar-by-soil interaction; E: error term/residual; $\ddagger$ Obtained by fitting the $\mathrm{C} \cdot \mathrm{S}$ model; $\S$ The unit does not apply to genetic correlation
The first Mega-E consisted of one environment, namely, Lithic Haplusterts, whereas the second Mega-E contained two environments, namely, Vertic Haplustalfs and Ustic Epiaquerts. Situ Patenggang (G14) exhibited the best performance in Lithic Haplusterts, whereas GM 28 (G5) had the best performance in Vertic Haplusterts and Ustic Epiaquerts (Figures 1.A and 1.B).

The stability of genotypes may be evaluated with AEC (Yan 2007). Situ Patenggang and GM 28 showed the highest mean yield in all soil types. However, genotype stability differed. The line length between the genotype and its orthogonal projection onto the biplot axis measures genotype stability. Short lines indicate high stability, whereas long lines indicate low stability. Situ Patenggang 
had long lines, so it was classified as an unstable cultivar. By comparison, GM 28 had short lines, so it had high stability (Figure 1.C).

The results of the GGE-biplot via the AEC method were strengthened by stability analysis with the Shukla model. This model showed that the effect of $\mathrm{C} \cdot \mathrm{S}$ varied widely between cultivars. Rice cultivars with small variance values were stable, whereas cultivars with high variance were unstable. In Table 5 , the highly stable cultivars were Ciherang (0.000), GM 8 (0.045), and IR-64 (0.038); the fairly stable cultivars were GM 2 (0.192), GM 11 (0.106), GM 8 (0.207), Inpari 6 Jete (0.776), Inpari 33 (0.380), and Way Apo Buru (0.959); and the unstable cultivars were Inpago 4 (1.751), Inpago 5 (1.784), Inpago 6
(2.227), Puthu Gunungkidul (1.230), Situ Bagendit (2.297), and Situ Patenggang (3.172).

A genotype is considered ideal if it has a high mean and stability. An ideal genotype can be recommended for evaluating a specific genotype. It is found in the first concentric circle, and the desired genotype is in the second concentric circle. Genotypes in the third and subsequent concentric circles are less desirable because they have poor results (Bilgin et al. 2015; Oladosu et al. 2017). In general, no ideal genotype for rice cultivars has been identified. However, Situ Patenggang and GM 28 cultivars were included in the desired genotype (Figure 1d). No superior rice cultivar was found under all environmental conditions. Alam et al. (2019b) stated that no ideal soybean cultivar had been tested on different soil types in $M$. cajuputi forests.
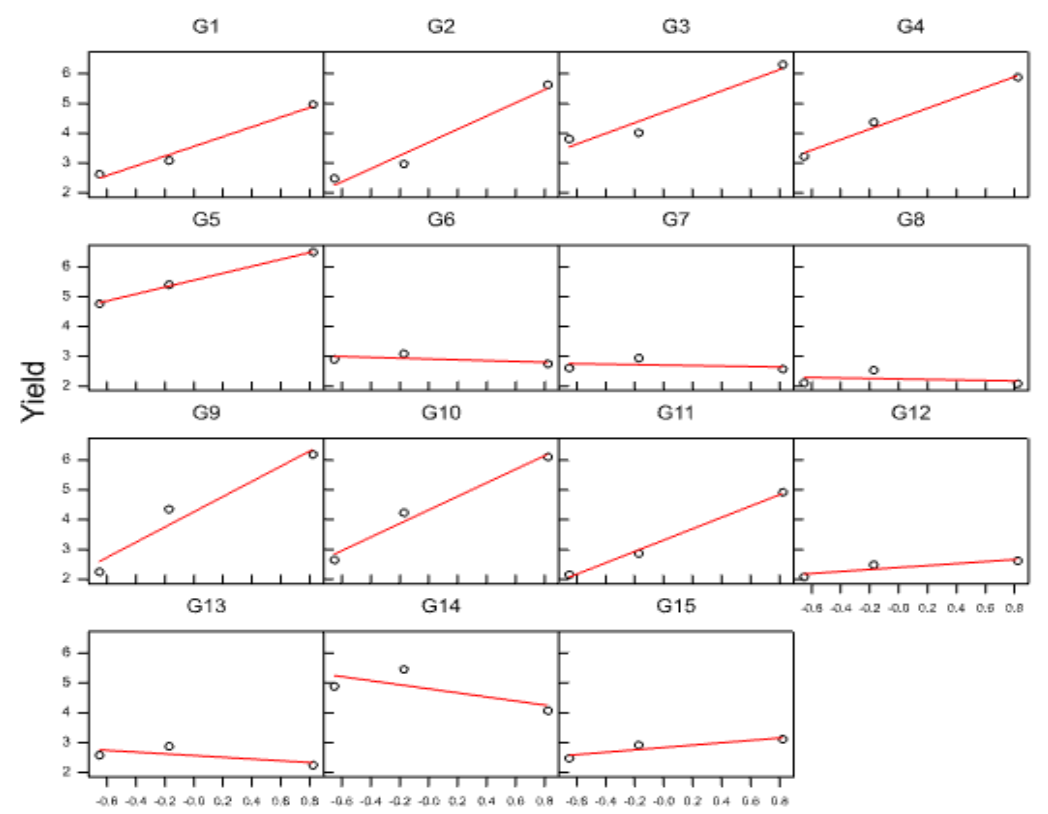

Environments

A
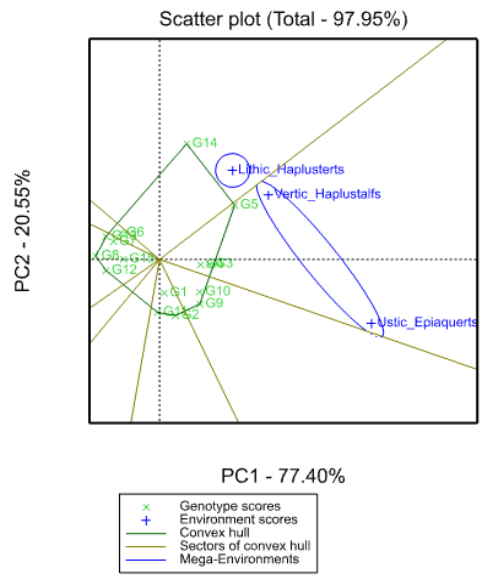

B

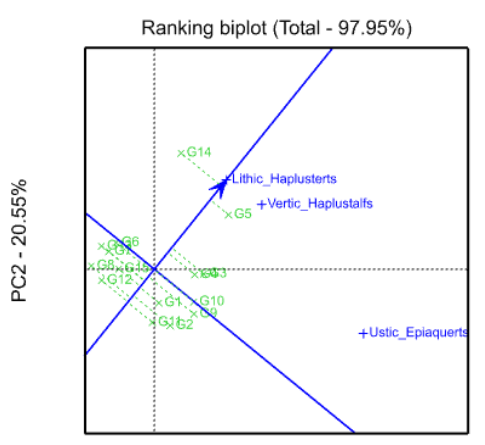

PC1 $-77.40 \%$

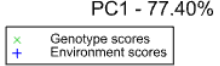

C

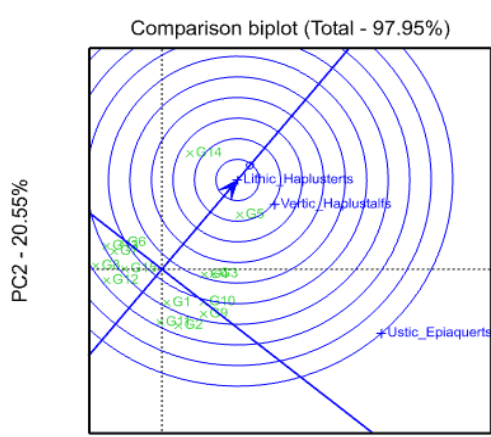

PC1 $-77.40 \%$

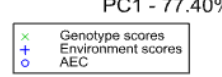

D

Figure 1. A. Performance of rice cultivars in different soil types; B. GGE-biplot polygon with a which-won-where pattern; C. AEC shows the GGE-biplot based on the environment-focused scaling of the mean value and stability of genotype; D. GGE-biplot based on genotype-focused scaling to compare a certain genotype with an ideal genotype. G1: Ciherang; G2: GM 2; G3: GM 8; G4: GM 11; G5: GM 28; G6: Inpago 4; G7: Inpago 5; G8: Inpago 6; G9: Inpari 6 Jete; G10: Inpari 33; G11: IR-64; G12: Puthu Gunungkidul; G13: Situ Bagendit; G14: Situ Patenggang; and G15: Way Apo Buru 
Table 5. Stability variance estimates $\left(10^{-3} \mathrm{~kg}^{2} \mathrm{ha}^{-2}\right)$ for the Shukla model

\begin{tabular}{lc}
\hline Cultivars & Stability variance estimate for $\mathbf{C} \cdot \mathbf{S}$ \\
\hline Ciherang & 0.000 \\
GM 2 & 0.192 \\
GM 8 & 0.045 \\
GM 11 & 0.106 \\
GM 28 & 0.207 \\
Inpago 4 & 1.751 \\
Inpago 5 & 1.784 \\
Inpago 6 & 2.227 \\
Inpari 6 Jete & 0.776 \\
Inpari 33 & 0.380 \\
IR-64 & 0.038 \\
Puthu Gunungkidul & 1.230 \\
Situ Bagendit & 2.297 \\
Situ Patenggang & 3.172 \\
Way Apo Buru & 0.959 \\
\hline
\end{tabular}

Variations in genotype performance across sites are often related to differences in environmental factors, such as temperature, relative humidity, total rainfall and distribution, light intensity, photoperiod, soil moisture, and cultural practices (Azam et al. 2020; Djidonou et al. 2020). Yan et al. (2003) reported that up to $80 \%$ of variations are due to environmental influences, whereas $20 \%$ of the total variations are attributed to GEI.

Each rice cultivar has different nutrient limiting factors. Suryanto et al. (2020b) indicated that Situ Patenggang cultivar is limited by the percentage of clay in the soil. In particular, the increase in the percentage of clay in the soil is significantly correlated with the increase in Situ Patenggang yield. Situ Patenggang cultivar is a type of upland rice, so it is more adaptive to and can grow well in Lithic Haplusterts and Vertic Haplustalfs because both soil types have a low soil water content (SWC).

GM 28 cultivar is limited by SOC and SWC. The increase in the percentage of SOC and SWC in the soil is correlated significantly with the increase in GM 28 yield. SWC is an essential element for plant growth. Lack of soil moisture has an impact on drought stress in rice. Low water content can interfere with photosynthesis, reducing leaf area, cell size, and intercellular volume and ultimately lower yields (Scherer et al. 2017; Xue et al. 2017). SOC is one of the chemical properties of soil that plays an essential role in increasing plant growth and is used as an indicator to assess soil health (Brandão and Canals 2013; Brady et al. 2015). GM 28, which is a type of lowland rice, is characterized by a high yield potential if water is needed. In this study, rice cultivars were unstable and had high yields for all soil types. Therefore, location-specific rice cultivars should be selected to obtain high yields. Aristya et al. (2021) reported that GM 28 has the highest mean yield per hectare (6.980 tons $\left.\mathrm{ha}^{-1}\right)$ in an irrigated paddy field in three districts in Central Java Province, Indonesia.

\section{ACKNOWLEDGEMENTS}

This research was fully funded by Universitas Gadjah Mada through the university grant-in-aid scheme under PTUPT 2021 (No.: 2133/UN1/DITLIT/DIT-LIT/PT/2021).

\section{REFERENCES}

Alam T, Kurniasih B, Suryanto P, Basunanda P, Supriyanta, Ambarwati E, Widyawan MH, Handayani S, Taryono. 2019a. Stability analysis for soybean in agroforestry system with kayu putih. SABRAO J Breed Genet 51 (4): 405-418.

Alam T, Suryanto P, Handayani S, Kastono D, Kurniasih B. 2020. Optimizing application of biochar, compost and nitrogen fertilizer in soybean intercropping with kayu putih (Melaleuca cajuputi). Rev Bras Cienc Solo 44: e0200003. DOI: 10.36783/18069657rbcs20200003

Alam T, Suryanto P, Kastono D, Putra ETS, Handayani S, Widyawan MH, Muttaqin AS, Kurniasih B. 2021. Evaluation of interactions between biochar briquette with ammonium sulfate fertilizer for controlled nitrogen loss in soybean intercropping with Melaleuca cajuputi. Legume Res 4 (3): 339-343. DOI: 10.18805/LR-586.

Alam T, Suryanto P, Nurmalasari AI, Kurniasih B. 2019b. GGE-Biplot analysis for the suitability of soybean varieties in an agroforestry system based on kayu putih (Melaleuca cajuputi) stands. Caraka Tani: $\begin{array}{lllll}\text { J Sustain Agric } 34 & \text { (2): 213-222. DOI: }\end{array}$ 10.20961/carakatani.v34i2.30434.

Aristya VE, Trisyono YA, Mulyo JH, Taryono. 2021. Participatory varietal selection for promising rice lines. Sustain 13 (6856): 1-18. DOI: $10.3390 /$ su13126856

Azam MG, Iqba MS, Hossain MA, Hossain MF. 2020. Stability investigation and genotype $\times$ environment association in chickpea genotypes utilizing AMMI and GGE Biplot model. Genet Mol Res 19 (3): gmr16039980.

Bilgili AV, Kucuk C, van Es HM. 2017. Assessment of the quality of the Harran Plain soils under long-term cultivation. Environ Monit Assess 189 (9): 1-15. DOI: 10.1007/s10661-017-6177-y

Bilgin O, Guzmán C, Baser I, Crossa J, Korkut KZ, Balkan A. 2015. Evaluation of grain yield and quality traits of bread wheat genotypes cultivated in Northwest Turkey. Crop Sci 56 (1): 73-84. DOI: 10.2135/cropsci2015.03.0148

Boettinger J, Chiaretti J, Ditzler C, Galbraith J, Kerschen K, Loerch C, McDanie P, McVey S, Monger C, Owens P, Ransom M, Scheffe K, Shaw J, Stolt M, Weindorf D. 2015. Illustrated Guide to Soil Taxonomy. Version 2. U.S. Department of Agriculture, Natural Resources Conservation Service, National Soil Survey Center, Lincoln, Nebraska, USA. DOI: 10.2136/sh2015-56-2-rc3

Boy R, Indradewa D, Putra ETS, Kurniasih B. 2020. Drought-induced production of reactive oxygen species and antioxidants activity of four local upland rice cultivars in Central Sulawesi, Indonesia. Biodiversitas 21 (6): 2555-2565. DOI: 10.13057/biodiv/d210628.

Brady MV, Hedlund K, Cong RG, Hemerik L, Hotes S, Machado S, Mattsson L, Schulz E, Thomsen IK. 2015. Valuing supporting soil ecosystem services in agriculture; a natural capital approach. Agron J 107 (5): 1809. DOI: 10.2134/agronj14.0597

Brandão M, Canals LMI. 2013. Global characterisation factors to assess land use impacts on biotic production. Int J Life Cycle Assess 18 (6): 1243-1252. DOI: 10.1007/s11367-012-0381-3

Buntaran H, Forkman J, Piepho HP. 2021. Projecting results of zoned multi-environment trials to new locations using environmental covariates with random coefcient models; Accuracy and precision. Theor App Genet 134 (5): 1513-1530. DOI: 10.1007/s00122-02103786-2

Buntaran H, Piepho HP, Hagman J, Forkman J. 2019. A cross-validation of statistical models for zoned-based prediction in cultivar testing. Crop Sci 59: 1544-1553. DOI: 10.2135/cropsci2018.10.0642

Buntaran H, Piepho HP, Schmidt P, Ryden J, Halling M, Forkman J. 2020. Cross-validation of stagewise mixed-model analysis of Swedish variety trials with winter wheat and spring barley. Crop Sci 60: 22212240. DOI: $10.1002 / \mathrm{csc} 2.20177$

Djaenudin D, Marwan H, Subagjo H, Hidayat A. 2011. Technical Instructions Land Evaluation for Agricultural Commodities. 
Indonesian Agency for Agricultural Research and Development, Ministry of Agriculture, Indonesia. [Indonesian]

Dijidonou D, Leskovar DI, Joshi M, Jifon J, Avila CA, Masabni J, Wallace RW, Crosby K. 2020. Stability of yield and its components in grafted tomato tested across multiple environments in Texas. Sci Rep 10 (1): 1-14. DOI: $10.1038 / \mathrm{s} 41598-020-70548-3$

Eberhart SA, Russell WA. 1966. Stability parameters for comparing varieties. Crop Sci 6: $36-40 . \quad$ DOI 10.2135/CROPSCI1966.0011183X000600010011X

European Union. 2012. Sustainable Agriculture for the Future We Want. International Cooperation and Development, European Commission, Brussels, Belgium.

FAO. 2015. Agroforestry. http://www.fao.org/forestry/agroforestry/80338/en/.

FAO. 2019. World Food and Agriculture Statistical Pocketbook 2019 http://www.fao.org/3/ca6463en/ca6463en.pdf.

Farshadfar E, Hassan Z, Reza M. 2013. Evaluation of phenotypic stability in chickpea genotypes using GGE-Biplot. Ann Bio Res 2 (6): 282292.

Finlay KW, Wilkinson GN. 1963. The analysis of adaptation in a plant breeding programme. Aust J Agric Res 14 (6): 742-754. DOI: 10.1071/AR9630742

Forkman J, Piepho HP. 2013. Performance of empirical BLUP and Bayesian prediction in small randomized complete block experiments. J Agric Sci 151 (3): 381-395. DOI: 10.1017/S0021859612000445

Gerrano AS, van Rensburg WSJ, Mathew I, Shayanowako AIT, Bairu MW, Venter SL, Swart W, Mofokeng A, Mellem J, Labuschagne M. 2020. Genotype and genotype $\times$ environment interaction effects on the grain yield performance of cowpea genotypes in dryland farming system in South Africa. Euphytica 216 (5): 1-11. DOI: 10.1007/s10681-020-02611-z

Giller KE, Tittonell P, Rufino MC, van Wijk MT, Zingore S, Mapfumo P, Adjeinsiah S, Herrero M, Chikowo R, Corbeels M, Rowe EC, Baijukya F, Mwijage A, Smith J, Yeboah E, van der Burg WJ, Sanogo OM, Misiko M, de Ridder N, Karanja S, Kaizzi C, K'ungu J, Mwale M, Nwaga D, Pacini C, Vanlauwe B. 2011. Communicating complexity; integrated assessment of trade-offs concerning soil fertility management within African farming system to support innovation and development. Agric Syst 104 (2): 191-203. DOI: 10.1016/J.AGSY.2010.07.002

Goedhart PW, Thissen JTNM. 2016. Biometris GenStat Procedure Library Manual $18^{\text {th }}$ Edition. Wageningen University and Research Center, NL.

Kartikawati NK, Rimbawanto A, Susanto M, Baskorowati L, Prastyono. 2014. Budidaya dan Prospek Pengembangan Kayu Putih (Melaleuca cajuputi). IPB Press, Bogor, Indonesia. [Indonesian]

Klee HJ, Tieman DM. 2013. Genetic challenges of flavor improvement in tomato. Trends in Genet 29 (4): 257-267. DOI 10.1016/j.tig.2012.12.003.

Kleinknecht K, Möhring J, Singh KP, Zaidi PH, Atlin GN, Piepho HP. 2013. Comparison of the performance of BLUE and BLUP for zoned Indian maize data. Crop Sci 53: 1384-1391. DOI: 10.2135/cropsci2013.02.0073

Littell RC, Milliken GA, Stroup WW, Wolfinger RD, Schabenberger O 2006. SAS for mixed models. $2^{\text {nd }}$ Edition. SAS Inst. Inc., Cary, NC.
Mulyani A, Nursyamsi D, Syakir M. 2017. Strategi pemanfaatan sumberdaya lahan untuk pencapaian swasembada beras berkelanjutan. Jurnal Sumberdaya Lahan 11 (1): 11-22. DOI: 10.21082/jsdl.v11n1.2017.11-22 [Indonesian]

Oladosu Y, Rafii MY, Abdullah N, Magaji U, Miah G, Hussin G, Ramli A. 2017. Genotype $\times$ environment interaction and stability analyses of yield and yield components of established and mutant rice genotypes tested in multiple locations in Malaysia. Acta Agriculturae Scandinavica, Section B - Soil Plant Sci 67 (7): 1-17. DOI: 10.1080/09064710.2017.1321138

Piepho HP, Nazir MF, Qamar M, Rattu AUR, Din RU, Hussain M, Ahmad G, Subhan FE, Ahmad J, Abdullah, Laghari KB, Vistro IA, Kakar MS, Sial MA, Imtiaz M. 2016. Stability analysis for a countrywide series of wheat trials in Pakistan. Crop Sci 56: 24652475. DOI: $10.2135 /$ cropsci2015.12.0743

SAS Institute. 2013. SAS System for Windows 9.4. SAS Institute, Inc., North Carolina, USA.

Scherer TF, Franzen D, Cihacek L. 2017. Soil, Water, and Plant Characteristics Important to Irrigation. NDSU Extension Service, North Dakota State University, USA.

Shukla GK. 1972. Some statistical aspects of partitioning genotypeenvironmental components of variability. Heredity 29 (2): 237-245. DOI: 10.1038/hdy.1972.87

Smith AB, Cullis BR, Thompson R. 2005. The analysis of crop cultivar breeding and evaluation trials; An overview of current mixed model $\begin{array}{lllllll}\text { approaches. J Agric Sci } 143 & \text { (6): 449-462. DOI: }\end{array}$ $10.1017 / \mathrm{S} 0021859605005587$

Soil Survey Staff. 2014. Key to soil taxonomy version 2. U.S. Department of Agriculture, Natural Resources Conservation Service, National Soil Survey Center, Lincoln, Nebraska, USA.

Statistics Indonesia. 2020. The harvested area and rice production in Indonesia 2019. Statistics Indonesia, Jakarta, Indonesia. [Indonesian]

Suryanto P, Kurniasih B, Faridah E, Nurjanto HH, Rogomulyo R, Handayani S, Kastono D, Muttaqin AS, Alam T. 2020a. Influence of furrow with organic material and Chromolaena odorata compost on upland rice productivity in an agroforestry system with Melaleuca cajuputi. Biodiversitas 21: 780-791. DOI: 10.13057/biodiv/d210246

Suryanto P, Taryono, Supriyanta, Kastono D, Putra ETS, Widyawan MH, Alam T. 2020b. Assessment of soil quality parameters and yield of rice cultivars in Melaleuca cajuputi agroforestry system. Biodiversitas 21 (2): 3463-3470. DOI:10.13057/biodiv/d210807

Suryanto P, Tohari, Putra ETS, Alam T. 2017. Minimum soil quality determinant for rice and 'kayu putih' yield under hilly areas. J Agron 16 (3): 115-123. DOI: 10.3923/ja.2017.115.123

Xue R, Shen Y, Marschner, P. 2017. Soil water content during and after plant growth influence nutrient availability and microbial biomass. J Soil Sci Plant Nutr 17 (3): 702-715. DOI: 10.4067/S071895162017000300012

Yan W, Kang MS, Ma B, Woods S, Cornelius PL. 2007. GGE-biplot vs. AMMI analysis of genotype-by-environment data. Crop Sci 47 (2): 643-655. DOI: $10.2135 /$ cropsci2006.06.0374

Yan W, Kang MS. 2003. GGE Biplot Analysis; A Graphical Tool for Breeders, Geneticists and Agronomists. $1^{\text {st }}$ Edition. CRC Press, Boca Raton, Florida, USA. DOI: 10.1201/9781420040371 